\title{
Overview of Soft-switching DC-DC Converters
}

\author{
Abdul-Hakeem Mohammed Dobi ${ }^{1}$, Mohd Rodhi Sahid ${ }^{2}$, Tole Sutikno ${ }^{3}$ \\ ${ }^{1,2}$ Department of Electrical Power System, School of Electrical Engineering, Universiti Teknologi, Malaysia, Skudai, \\ Johor Bahru. Malaysia \\ ${ }^{3}$ Department of Electrical Engineering, Universitas Ahmad Dahlan, Indonesia
}

\begin{tabular}{|c|c|}
\hline Article Info & ABSTRACT \\
\hline Article history: & Application of soft switching in DC-DC converter has achieved a remarkable \\
\hline Received May 16, 2018 & $\begin{array}{l}\text { success in power electronics technology in terms of reduction in switching } \\
\text { losses, improve in power density, minimization of electromagnetic }\end{array}$ \\
\hline Revised Oct 13, 2018 & interference (EMI) and reduction in the volume of DC-DC converters. Quite \\
\hline Accepted Oct 28, 2018 & $\begin{array}{l}\text { a number of soft switching techniques had been reported in the past four } \\
\text { decades. This paper aims at providing a review of various soft switching }\end{array}$ \\
\hline Keyword: & $\begin{array}{l}\text { techniques, based on topology, the location of the resonant network, } \\
\text { performance characteristics, and principles of operation. In addition, }\end{array}$ \\
\hline $\begin{array}{l}\text { Soft-switching } \\
\text { DC-DC converter }\end{array}$ & $\begin{array}{l}\text { converters area of application, advantages as well as limitations are also } \\
\text { highlighted. }\end{array}$ \\
\hline
\end{tabular}

Resonant converters

ZVS

ZCS

Corresponding Author:

Abdul-Hakeem Mohammed Dobi, Department of Electrical Power System,

School of Electrical Engineering,

Universiti Teknologi Malaysia, 81310 Skudai Johor Bahru, Malaysia.

Email: 1sntl@ccu.edu.tw

\section{INTRODUCTION}

Load requirements of most electrical equipment are not always compatible with that of sources of electrical energy like photovoltaic cells, utility supply, batteries etc. For electrical equipment to effectively utilize these energy sources, there is a need for an interface between these sources and the receiving end. Generally, the (DC-AC or DC-DC) converter is a popular and commonly used interface for this purpose.

Computers un-interrupted power supplies (UPS), renewable energy systems, vehicle auxiliary power supplies all require a high step-up voltage gain from a DC-DC converter. However, due to the narrow duty cycle of a conventional boost converter, such requirement cannot be met [1], [2]. Achieving a high voltage gain by a pulse width modulated (PWM) DC-DC converter becomes a major problem due to a simple fact that; during turning $\mathrm{ON}$ and $\mathrm{OFF}$ of the power switches very fast transition of voltage $\left(\frac{\delta v}{\delta t}\right)$ and current $\left(\frac{\delta i}{\delta t}\right)$ occurs on the power switches. These changes may lead to the generation of electromagnetic interferences (EMI) noise which may exceed the permitted level in the power lines. On the other hand, power dissipation will rise during the transition of states resulting from the existence of current through and the voltage across the switches. This happens due to the fact that, in the cause of closing a switch, maximum current through it is established and the voltage across the switch is the same as when it was open. Due to demand for small converter size and high power density, a severe effect can be observed since these converters are required to operate at a high switching frequency [3]-[5]. Furthermore, since losses in these converters increase as a results of increase power dissipation, reducing switching losses significantly increases power density and efficiency of the converters [6]-[11]. To overcome the problems of EMI, switching losses and low efficiency, soft switching techniques is a worthy solution [3], [12]-[14]. High power density, high reliability, reduced 
volume and lower ratings of components can be achieved with a high-switching frequency and soft-switching converters [3], [15]-[20].

In soft switching techniques, higher frequency resonant network is added to hard switching topology to shape the switching waveform with the intent of minimizing the switching losses, EMI and switching stress [16], [21]. Two commonly soft-switching methods are; zero-voltage-switching (ZVS) and zerocurrent-switching (ZCS) [14] respectively. A number of soft-switching using either ZVS or ZCS to reduce switching losses in power converters operating at high switching frequency are reported [12], [22]-[34]. One of the widely used methods of achieving soft-switching is using a resonant tank.

This paper aims to provide a review of various soft-switching techniques, with reference to families, the location of the resonant circuit, mode of connection of the resonant elements and voltage-current waveforms behavior. Three major families' classifications are considered i.e. quasi-resonant converters (QRC), multi-resonant converters (MRC) and resonant transition converters (RTC). The three families are later classified into several categories as discussed in the following topics:

Discussion on the family classification of resonant converters including their different subcategories is given in the second section of this paper. The third section concludes and summarizes the paper.

\section{CLASSIFICATION}

Resonant converters are obtained by adding a resonant active snubber to conventional PWM converters for the achievement of suitable combine features of resonant converters and PWM converters [16], [17], [35]. These converters classification are categorized on the basis of the number of reactive elements in the resonant network, location of the elements in the converter, (i.e. load side, or switch side), mode of connection of resonant network (series, parallel or series-parallel), and the behaviour of the switching (ZVS, ZCS). Figure 1; shows the classification of resonant converters and topologies.

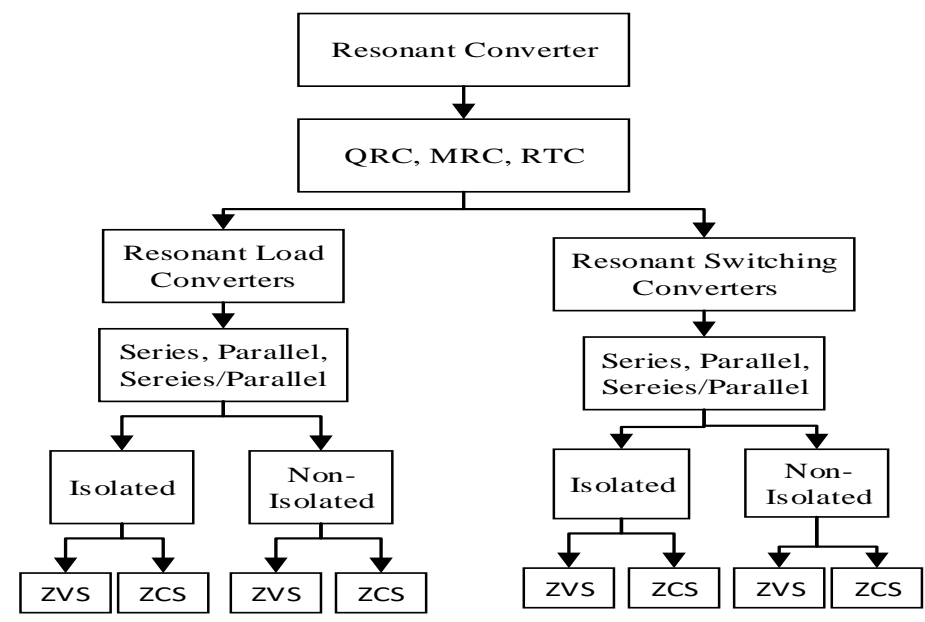

Figure 1. Classification of resonant converters

\subsection{Quasi-Resonant Converters (QRC)}

These converters are reported in [14], [21], [36], [37]. In principle, QRC consists of only two auxiliary components made up of one inductor and one capacitor $\left(L_{r}\right.$, and $\left.C_{r}\right)$. Depending on configuration or converter application, the auxiliary element can be connected in series or parallel or both (series-parallel). In addition, the series-parallel connection can be either with respect to the switch or load of a particular converter. All this is targeted at obtaining ZVS, ZCS, zero voltage transition (ZVT) or zero current transition (ZCT) on either the switch or the diode. This is with respect to how the reactive elements are connected with the switch and diode [38]. However, this configuration, in spite of its simple design and low current stress for the switches, simultaneous soft-switching for both the diode and the switch is not feasible [39]. Furthermore, in ZVS-QRC (single ended), the active switch is subjected to excessive voltage stress [39], [40] which is proportional to the load range. This makes them suitable for low power applications [14] In addition, resonant peak voltage demands highly rated device [41]. Although, the active switch and the diode operates at ZVS \& ZCS, the parasitic junction capacitance of the rectifier diode interact with the large resonant inductor, resulting in large noise from switching oscillation. Figure 2 (a) shows ZVS-QRC with a resonant 
capacitor $\left(C_{r}\right)$ shunted across the main switch to achieve ZVS while Figure 2 (b) shows ZCS-QRC with resonant inductors $\left(L_{1}, L_{2}\right)$ connected in series with the switches $\left(S_{1}\right.$ and $\left.S_{2}\right)$ to facilitates in ZCS turn-on of the switches.

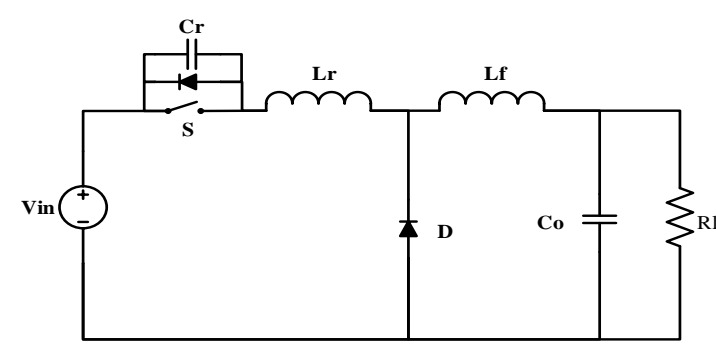

(a)

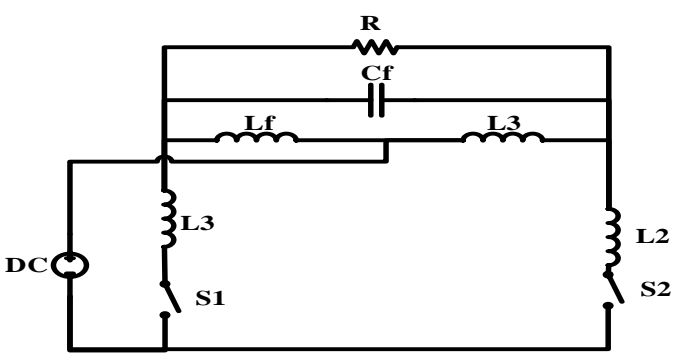

(b)

Figure 2. QRC (a) ZVS-QRC [37] and (b) ZCS- QRC [21]

\subsection{Multi-Resonant Converters (MRC)}

MRCs are modified version of QRC consisting of multiple reactive components as reported in [42][46]. The reactive elements composing of two resonating inductors and one resonance capacitor $\left(L_{s}, L_{m}\right.$ and $\left.\mathrm{C}_{\mathrm{s}}\right)$ as depicted in Figure 3. The two modes of connection for achieving ZVS and ZCS is reported in [38]. Depending on the mode of operation, ZVS or ZCS can be simultaneously provided for both the diode and the switch respectively. Hence, MRC are known as double-ZVS or double-ZCS converters. In ZVSMRC all semiconductor devices operates at zero-voltage switching, thereby, significantly reducing noise and switching losses, at the expense of increased conduction losses, as a result of high circulating current. Consequently, both active and passive switches suffers from voltage and current stresses. These converters are suitable for high frequency operation and in comparison with QRC their voltage and current stress are moderate.

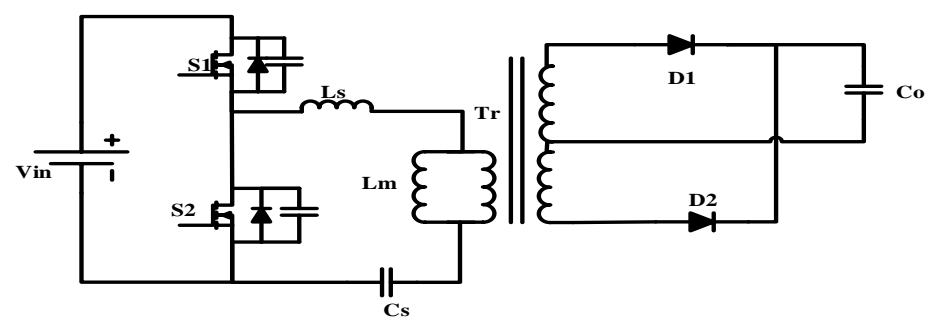

Figure 3. LLC series resonant MRC(45)

\subsection{Resonant Transition Converter (RTC) or Zero Transition Converters (ZTC)}

RTC utilizes four auxiliary elements consisting of two auxiliary resonant tanks $(\mathrm{L}, \mathrm{C})$, and two auxiliary switches. Detailed analysis of these converters can be found in [47]-[50]. RTC is designed to provide zero-current transition (ZCT) [10], [13], [51], [52] or zero-voltage transition (ZVT) as reported in [8], [12], [53]-[55]. ZCT is designed to make the main switch turn-off when the current flow through it is zero. However, ZVT technique is intended to make the main switch turn-on from turn-off state as the voltage across the switch becomes zero. Figure 4 (a) and (b) shows the ZCT and ZVT converters respectively. ZTC are mostly affected by hard switching of the auxiliary switch, limitation in voltage conversion range, high circulating current, high peak current/voltage stress, and additional conduction losses. In addition, resonant transition (RT) PWM converters operate near boundary conduction mode, allowing an additional resonant transition phase to bring the switch voltage to zero [20], [41]. Achievements of true zero voltage switching (ZVS) by the majority of these converters is only possible across limited voltage range. Table 1 summarises some of the advantages and disadvantages of QRC, MRC, and RTC as well as their associated losses and stresses. Furthermore, Table 2 is a summary of three major families of soft-switching converters, with respect to the number of count of the auxiliary components $(\mathrm{L}, \mathrm{C})$ in each family as well as their corresponding 
auxiliary switch. It can be confirmed from Table 1 that RTC has a higher number of auxiliary components in comparison with QRC and MRC respectively. Consequently, Table 3 gives general remarks on the softswitching condition of the three families of the converter.

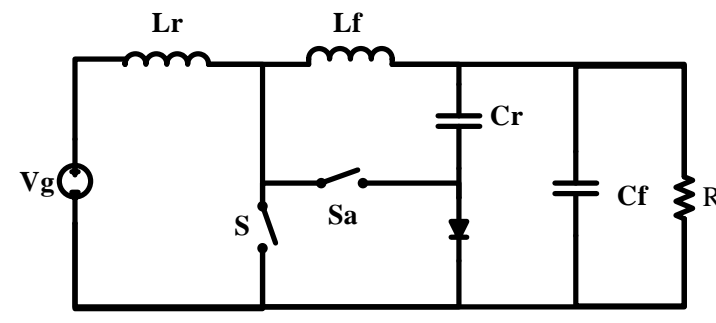

(a)

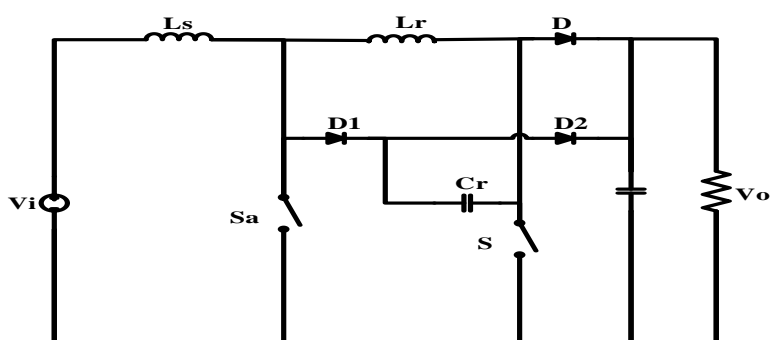

(b)

Figure 4. Resonant transition converters (a) ZCT (b) ZVT

Table 1. Comparison of the Main Properties of QRC, MRC, and RTC

\begin{tabular}{|c|c|c|c|c|c|c|c|}
\hline $\begin{array}{l}\text { Conve } \\
\text { rter } \\
\text { Family }\end{array}$ & Switching losses & $\begin{array}{c}\text { Conduction } \\
\text { losses }\end{array}$ & $\begin{array}{c}\text { Voltage } \\
\text { stress }\end{array}$ & $\begin{array}{c}\text { Current } \\
\text { stress }\end{array}$ & Application & Merit & Demerits \\
\hline QRC & $\begin{array}{l}\text { Severe switching } \\
\text { noise due to the } \\
\text { interaction of } \\
\text { rectifier diodes, } \\
\text { parasitic } \\
\text { capacitance with } \\
\text { the large resonant } \\
\text { inductor }\end{array}$ & $\begin{array}{l}\text { Losses due to } \\
\text { high circulating } \\
\text { current which } \\
\text { leads to low } \\
\text { power density } \\
\text { and efficiency }\end{array}$ & $\begin{array}{l}\text { Excessive } \\
\text { voltage } \\
\text { stress } \\
\text { proportiona } \\
1 \text { to the load } \\
\text { range }\end{array}$ & $\begin{array}{l}\text { Low } \\
\text { current } \\
\text { stress for } \\
\text { the active } \\
\text { switch }\end{array}$ & $\begin{array}{l}\text { Suitable for } \\
\text { low power } \\
\text { application }\end{array}$ & $\begin{array}{l}\text { Low } \\
\text { compone } \\
\text { nts count } \\
\text { compared } \\
\text { to MRC } \\
\text { and RTC } \\
\text { converter } \\
\text { s }\end{array}$ & $\begin{array}{l}\text { Rely heavily on } \\
\text { frequency control; } \\
\text { additional } \\
\text { resonant peak } \\
\text { voltage } \\
\text { necessitates more } \\
\text { highly rated } \\
\text { device. }\end{array}$ \\
\hline MRC & $\begin{array}{l}\text { Reduced } \\
\text { switching losses } \\
\text { and noise }\end{array}$ & $\begin{array}{l}\text { Increase in } \\
\text { conduction } \\
\text { losses owing to } \\
\text { smaller filter } \\
\text { and reactive } \\
\text { components }\end{array}$ & $\begin{array}{l}\text { moderate } \\
\text { voltage } \\
\text { stress for } \\
\text { the active } \\
\text { and passive } \\
\text { switches } \\
\text { compared } \\
\text { to QRC }\end{array}$ & $\begin{array}{l}\text { Moderate } \\
\text { current } \\
\text { stress for } \\
\text { both } \\
\text { active } \\
\text { and } \\
\text { passive } \\
\text { switch }\end{array}$ & $\begin{array}{l}\text { Suitable for } \\
\text { high- } \\
\text { frequency } \\
\text { operation, } \\
\text { such as } \\
\text { LCD/LED } \\
\text { drivers, } \\
\text { power supply } \\
\text { chip for } \\
\text { Microprocess } \\
\text { or unit etc. }\end{array}$ & $\begin{array}{l}\text { Wider } \\
\text { control } \\
\text { dynamics } \\
\text {, All } \\
\text { power } \\
\text { switches } \\
\text { operate } \\
\text { with ZVS }\end{array}$ & $\begin{array}{l}\text { High circulating } \\
\text { current, excessive } \\
\text { voltage stress due } \\
\text { to the resonant } \\
\text { effect of leakage } \\
\text { inductance and } \\
\text { device parasitic } \\
\text { capacitance }\end{array}$ \\
\hline RTC & $\begin{array}{l}\text { Lower switching } \\
\text { losses than PWM } \\
\text { converters }\end{array}$ & $\begin{array}{l}\text { Increase in } \\
\text { conduction } \\
\text { losses due to } \\
\text { additional } \\
\text { components }\end{array}$ & $\begin{array}{l}\text { Low } \\
\text { voltage } \\
\text { stress }\end{array}$ & $\begin{array}{l}\text { Low } \\
\text { current } \\
\text { stress }\end{array}$ & $\begin{array}{l}\text { Suitable for } \\
\text { high power } \\
\text { application }\end{array}$ & $\begin{array}{l}\text { High } \\
\text { power } \\
\text { density \& } \\
\text { efficienc } \\
\text { y }\end{array}$ & $\begin{array}{l}\text { Complex control } \\
\text { system. The } \\
\text { auxiliary switch } \\
\text { does not } \\
\text { commutate softly. } \\
\text { Limited range of } \\
\text { ZVS }\end{array}$ \\
\hline
\end{tabular}

Table 2. Number of Resonant Elements base on the Family of Resonant Converters

\begin{tabular}{cccccc}
\hline S/N & Family & $\begin{array}{c}\text { Number of } \\
\text { Auxiliary elements }\end{array}$ & $\begin{array}{c}\text { Number of Resonant } \\
\text { Capacitor }\end{array}$ & $\begin{array}{c}\text { Number of Resonant } \\
\text { Inductor }\end{array}$ & $\begin{array}{c}\text { Auxiliary } \\
\text { Switch }\end{array}$ \\
\hline 1. & QRC & 2 & 1 & 1 & 0 \\
2. & MRC & 3 & 1 or 2 & 1 or 2 & 0 \\
3. & RTC & 4 & 1 & 1 & 2 \\
\hline
\end{tabular}

Table 3. General Remarks on the Family Classification of Resonant Converters

\begin{tabular}{ccl}
\hline N & FAMILY & \multicolumn{1}{c}{ REMARKS } \\
\hline 1. & QRC & $\begin{array}{l}\text { Does not Produce simultaneous soft switching for the switch and the diode. } \\
\text { Both switch and diode produce soft switching simultaneously. }\end{array}$ \\
2. & MRC & $\begin{array}{l}\text { LLC \& LCC topology have a desirable relationship between frequency and gain as a smaller change in } \\
\text { frequency results into significant change in gain, as against the regular resonant converters. }\end{array}$ \\
3. & RTC & $\begin{array}{l}\text { Hard switching for all switches, provide soft switching only during switching commutation, provides } \\
\text { additional voltage/current stresses on the main switch and the diode }\end{array}$ \\
\hline
\end{tabular}


Resonant converters can be classified on the basis of the location of the resonant network in the converter circuit. The details are explained in the proceeding topics.

\section{a. Resonant switch converters:}

These converters consists of a resonant tank network, which is connected in series or parallel or hybrid (series-parallel) with the switch. Figure 2(a) and 2(b) are an example of such converters, where a resonant capacitor is connected in parallel with the switch and a resonant inductor connected in series with the switch respectively. The series, parallel or hybrid connection can be in the form of isolated series resonant switching converters [14], [56], [57], [42] or non-isolated series resonant switching converters [58], isolated parallel resonant switching converters [25]. An isolated parallel resonant switch converter consists of a parallel capacitor connected with the power switches to provides ZVS and non-isolated parallel resonant switching converters consisting of one or more element in parallel with the switch.

Due to the fact that, in series resonant converters, resonant elements are connected in the main power path, subjecting the resonant inductor to bidirectional voltage, and consequently, generating additional voltage stress on the semiconductor devices. In addition, conduction losses are significantly increased due to substantial circulating energy as a result of all power flowing through the resonant inductor.

However, in parallel resonant switch converter, the shunt resonant circuit is activated for partial resonance to attain ZVS or ZCS during switching transition. Consequently, the circuit reverts back to PWM operating mode after switching transition.

\section{b. Resonant load converters:}

In this configuration, the load appears in series, parallel or series-parallel with the resonant tank. In a series-parallel resonant load converter, the resonant capacitor (oscillatory) is divided into two sections, by connecting one in parallel with the load and the other one in series with the coil. Thereby, forming a seriesparallel network between the load and the oscillatory circuit. Such converters can have a galvanic isolation between the source and the load (isolated) [59] or non-isolated type, as reported in [25], [56] to provide ZVS $\&$ ZCS respectively. Due to the series connection of the resonant element in power flow path, the components suffer from voltage and current stress, this limited their application in high power levels. Resonant load converters are therefore suitable in constant load application. however, turning the load of this converter close to resonant frequency provides good voltage regulation.

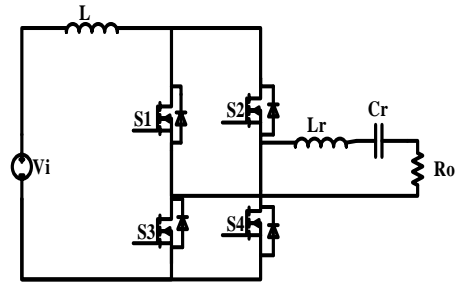

(a)

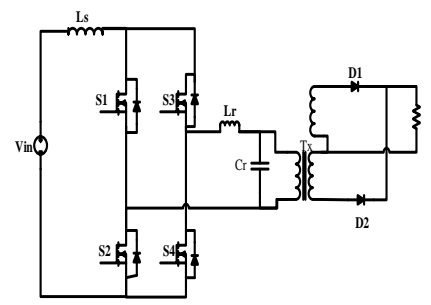

(b)

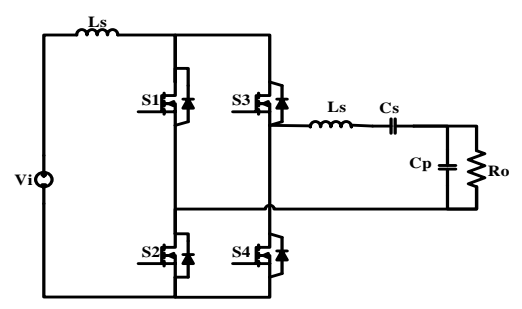

(c)

Figure 5. Resonant load converters (a) series resonant. (b) Parallel Resonant. (c) series-parallel Resonant

Due to the parallel resonant capacitor at the transformer secondary as shown in Figure $5 \mathrm{~b}$ the diodes are soft-switched, and the diode capacitance formed part of parallel resonant capacitance. This facilitates high switching frequency operation of the load resonant circuit, and easily operated in ZCS mode by operating below the resonant frequency. Perhaps, this requires snubber diodes, very high voltage transformer as well as high-speed diodes. Consequently, series loaded resonant converters are most suitable for high voltage, low current applications. While parallel-load resonant converters are mostly used in low-voltage, high-current applications. The series-parallel resonant converters can run over a wider input voltage and load [60]. In addition, load resonant converters allow size and weight reduction as a result of their high-frequency operation without sacrificing conversion efficiency. This aspect makes them suitable for high-frequency applications. [61] Operation of these converters depends on operating point and resonance frequency making them unsuitable for a wide range of operating conditions.

\section{c. Series, Parallel and Series-Parallel Resonant Converters:}

A load of these converters is connected in series, parallel or series-parallel with the oscillatory (auxiliary) circuit as indicated in Figure 6 (a), (b) and (c) respectively. Series resonant converter (SRC) are 
reported in [42], [34], [62]. Compared to hard switched converters SRC has lower EMI, reduced the size and lower losses due to switching. They provide much high power supplies and improved in conversion efficiency [63], [64]. Perhaps, SRC is associated with much more nonlinear dynamics hence, much more complex to control [63], [65]. However, at no load condition, the output voltage of SRC cannot be regulated. In parallel resonant converters (PRC), the resonant capacitor is connected in parallel with the load through transformer coupling which is not mandatory.

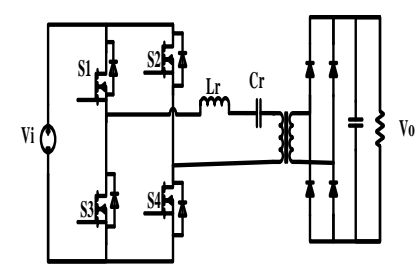

(a)

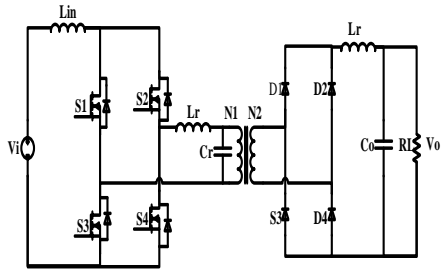

(b)

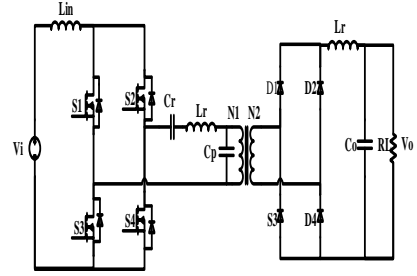

(c)

Figure 6. Resonant converter (a) series resonant converter [62] (b) Parallel resonant converters (c) SeriesParallel resonant converters

Unlike SRC, PRC can operate at no-load. ZVS can be achieved with the converter operating above resonance frequency. These converters have a high circulating current and they are inherently short-circuit protected. Series-parallel converters as reported by a number of authors as "LLC type parallel resonant converters" or converter using LCC- type commutation or hybrid converters [66]-[69], posses a combine attractive features of both series and parallel resonant converters.

Hence, the above-discussed converters can further be categorized on the basis of their voltagecurrent waveforms behavior. Soft-switching PWM can be classified into four main groups as ZVS, ZCS, ZVT, and ZCT respectively. Soft-Switching is provided by ZVS \& ZCS; thus, ZVT \& ZCT are advanced, so switching power loss can be completely destroyed or diverted to entry or exit [18], [50].

\section{d. Zero Voltage Switching (ZVS):}

Basically, in ZVS, switching occurs at the zero-voltage condition of the turn-on device, by making the switch voltage zero and slowing down the voltage rise creating a time delay for the current so that current transition occurs when the voltage is zero [16], [41] ZVS eliminates capacitive turn-on loss, and grossly reduced switching losses [16]. A number of converters using this switching technique are reported in [25], [70]-[81], the topologies of which can be either isolated type [56], [57], [70], [71], [74], [77], [80]-[82] to achieve galvanic isolation and voltage scaling or non-isolated type [72], [75], [76], [79], [83]. A ZVS for a bridgeless power factor correction (PFC) boost converter operating in continuous conduction mode (CCM) was reported in [84], this provides ZVS for the switches and reduces switching losses. Similarly, the heat management problem associated with traditional diode rectifier [85] has been eliminated due to the controlled transition in the output diode current at turn-off. These converters depend on soft switching for highefficiency operation. Thus, at high frequency, these features cannot be guaranteed at variable operating conditions [41]. Figure 7, illustrates a basic single-ended type ZVS constant voltage (CV) converter.

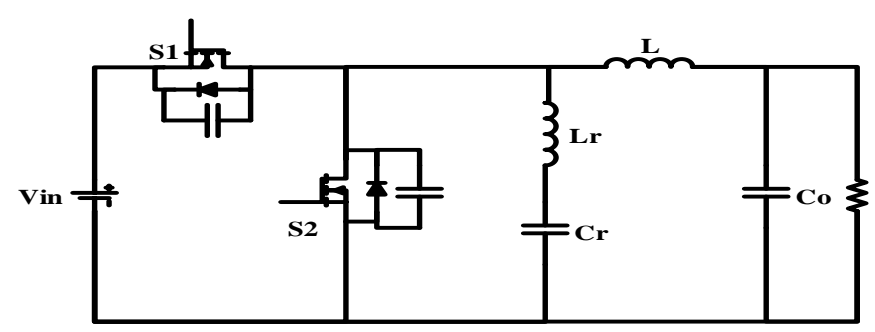

Figure 7. Basic single-ended type ZVS-CV converter 


\section{1) Zero Current Switching (ZCS):}

These converters are reported in [44], [86]-[98]. ZCS reduce switching losses at turn-off by forcing the switch current to zero, before its drain-source voltage increase from zero to turn-off static value. ZCS at turn-off facilitates in removing the stored charges which might cause a long current tail. This feature makes ZCS highly desirable [97]. Figure 8(a) and 8(b) shows a full bridge resonant ZCS boost converter and a full bridge resonant ZCS boost converter with parallel auxiliary circuit respectively. However, the majority of the ZCS proposed in literature reduced switching losses at the expense of increase conduction losses. This is due to high circulating energy caused by the resonant inductor in series with the power switch. This action exposes the power switch to a high current stress and a rectifier diode to high voltage stress. Another limitation of ZCS is the severe parasitic ringing of the power switch. As a results of non-utilization of the output capacitance of the power switch, the capacitance oscillates with the resonant inductor when the switch turn-off causing parasitic ringing. The low frequency parasitic ringing causes significant switching loss, noise and increase in voltage stress of the power switch. In addition, ZCS operates with constant on-time control. ZCS are more effective in IGBT switching losses reduction than ZVS particularly at low frequency [44] and high power application where minority carrier devices are used as a power switch.

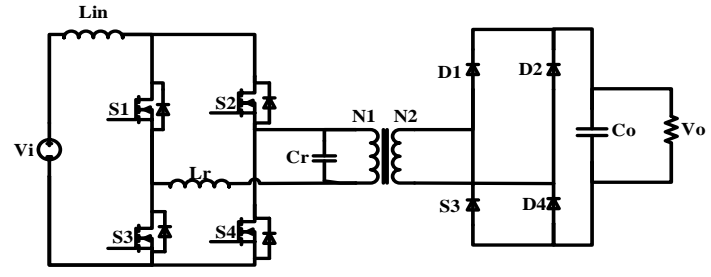

(a)

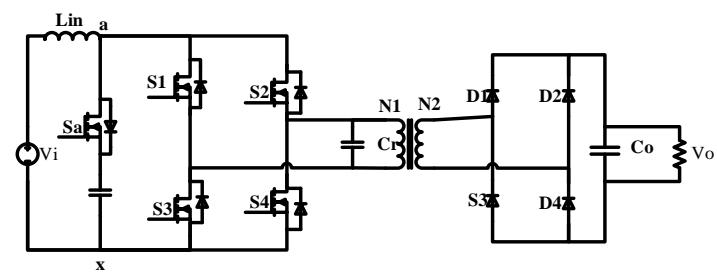

(b)

Figure 8. (a) Resonant ZCS full-bridge boost converter [89] (b) Resonant ZCS full-bridge boost converter with parallel auxiliary circuit

\section{2) Zero-voltage zero-current switching (ZVZCS):}

A number of converters are proposed by different authors to provide ZVZCS [98] for the main switch and diode simultaneously. Some of which are isolated [22], [43], [99]-[101] and non-isolated [4], [35], [58], [102]-104]. Figure 9 (a) and 9 (b) illustrates an isolated type ZVZCS converter and an interleaved ZCSZVS boost converters respectively.

ZVZCS for an interleaved boost converter had also been reported in [105]. The technique provides ZVS for all active and passive semiconductor device during turn-on and turn-off conditions, over a wide output load variation and the auxiliary switch operates at ZCS. Beside significant reduction in voltage and current stress in these converters, the converter does not support variable frequency operations.

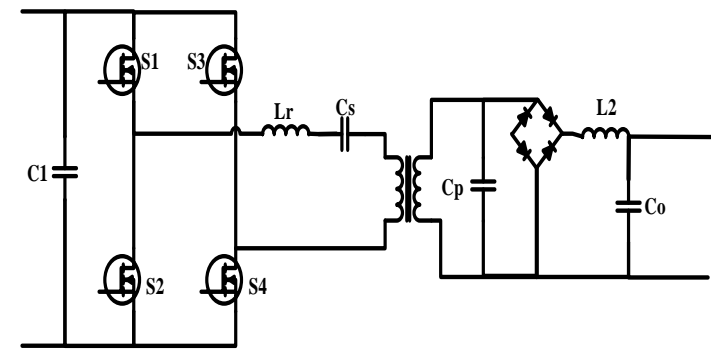

(a)

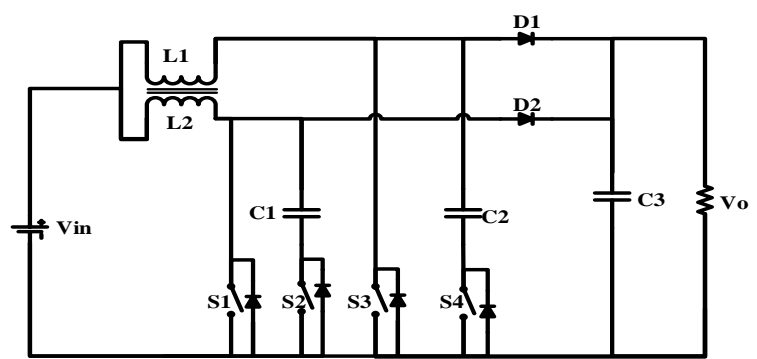

(b)

Figure 9. ZVZC Converters (a) Isolated type ZVZCS (b) Interleaved ZCS-ZVS boost Converter(58)

\section{3) Zero current transition (ZCT):}

Converter Figure 10 shows a basic ZCS converter with a couple of resonant elements $\left(L_{r} \& C_{r}\right)$, an auxiliary switch and diode $\left(S_{a} \& D_{a}\right)$ respectively. ZCT technique can significantly reduce turn-off switching 
losses through forcing to zero the outgoing switch current prior to its turn-off [106]. Some of the attractive features of ZCT are: minimum circulating current, variable load operation, low voltage and current stresses on the main switch and diode. Perhaps, one of the major drawbacks of these converters is hard switching at turn-on for the main switch and main diode at turn-off, given rise to large reverse recovery losses. In addition, ZCT converters does not support variable switching frequency operation [107].

Similarly, ZCT converter has high voltage stress for the diodes which is twice as high as in the PWM converters. Another drawback is the voltage swing that appears across the main switch (S1) due to the interaction between its output capacitance and resonant inductor [38].

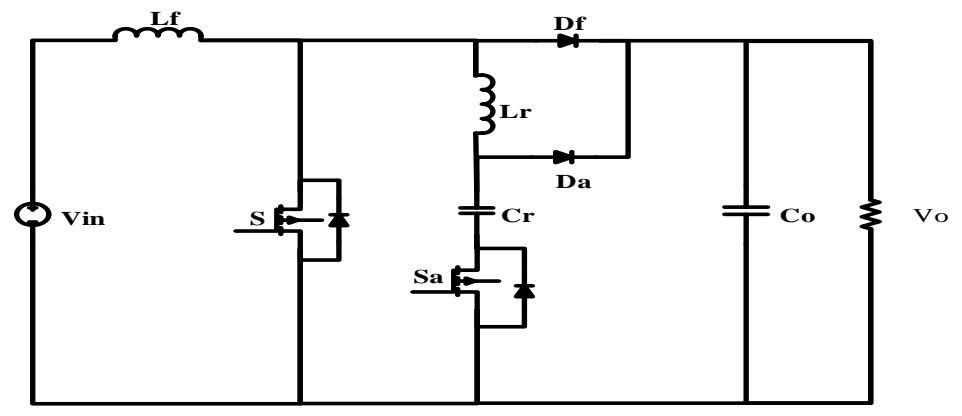

Figure 10. Basic ZCT converter

\section{4) Zero voltage transition (ZVT) Converters:}

In these converters are set of diodes, an auxiliary switch, and a snubber cells $\left(L_{r} \& C_{r}\right)$ the snubber circuit can be passive snubber or an active snubber cell [17], shunted across the main switch [108]. The shunt resonant network is activated to create a partial resonant during the switching transition to achieve ZVS or ZCS. Figure 11 depicts a conventional boost type ZVT converter. After switching transition the shunt resonant network is disable and the operation of the converter during most of the switching cycle is similar to that of PWM converters. In ZVT auxiliary switch does not commutate softly. However, it has a lower switching losses when compared to PWM converters [38]. In addition, ZVT has a complicated control circuit as well as additional conduction losses due to addithe tional auxiliary circuit [108].

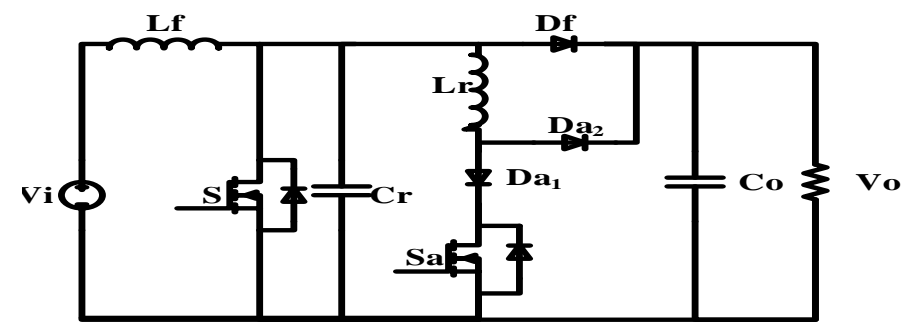

Figure 11. Conventional ZVT converter

Furthermore, ZVT PWM technique provides ZVS for the power switch and the rectifier diodes, it is, therefore, more attractive in higher voltage application (power factor correction circuit) where reverse recovery problem of the higher-voltage diode is of primary concern [16], [109], [110]. Table 4 gives highlights of features of resonant converters in terms of their current and voltage behaviors. 
Table 4. Features of Resonant Converters Based Voltage Current Waveforms Behaviour

\begin{tabular}{|c|c|c|c|c|}
\hline & $Z V S$ & $Z C S$ & $Z V T$ & $Z C T$ \\
\hline Merits & $\begin{array}{l}\text { - Grossly, reduced } \\
\text { switching losses } \\
\text { - Eliminates turn- } \\
\text { on losses of the } \\
\text { parasitic } \\
\text { capacitance and } \\
\text { Miller effect } \\
\text { - Low current stress }\end{array}$ & $\begin{array}{l}\text { Eliminates switching losses } \\
\text { during device turn-off \& } \\
\text { switching losses at turn-on }\end{array}$ & $\begin{array}{l}\text { - Small Voltage/current } \\
\text { rating and size of the } \\
\text { auxiliary components } \\
\text { - Provides soft-switching } \\
\text { without increasing voltage } \\
\text { or current stress on the } \\
\text { switch } \\
\text { - ZVT PWM have a } \\
\text { combine advantage of } \\
\text { Conventional PWM \& } \\
\text { resonant converters }\end{array}$ & $\begin{array}{l}\text { Minimum circulating } \\
\text { current, minimum } \\
\text { voltage/current stress } \\
\text { - Variable load } \\
\text { operation. } \\
\text { - low voltage stresses on } \\
\text { the diode and low } \\
\text { voltage/current the } \\
\text { main switch } \\
\text { reduced turn-on \& } \\
\text { turn-off losses of the } \\
\text { main switch }\end{array}$ \\
\hline Demerits & $\begin{array}{l}\text { The switches if } \\
\text { without voltage } \\
\text { clamping, will } \\
\text { be subjected to } \\
\text { excessive } \\
\text { voltage stress, } \\
\text { proportional to } \\
\text { the load }\end{array}$ & $\begin{array}{l}\text { - High capacitive turn-on } \\
\text { losses proportional to the } \\
\text { switching frequency. } \\
\text { - High circulating energy, } \\
\text { exposing the power switch } \\
\text { to a high current stress and } \\
\text { rectifier diode to high } \\
\text { voltage stress } \\
\text { - Significant power loss at } \\
\text { high voltage and high } \\
\text { frequency due to energy } \\
\text { discharge through the } \\
\text { switches by the capacitor at } \\
\text { turned on }\end{array}$ & $\begin{array}{l}\text { - Lower power density } \\
\text { - Harder control than } \\
\text { normal PWM converters } \\
\text { - Circuit operation depends } \\
\text { on line and load } \\
\text { conditions. } \\
\text { - Limited voltage } \\
\text { conversion range. } \\
\text { - For ZVT-PWM the } \\
\text { auxiliary switch does not } \\
\text { operate with soft- } \\
\text { switching } \\
\text { - The auxiliary switch is } \\
\text { used for providing ZVT or } \\
\text { ZCT for the main switch } \\
\text { but does not contribute to } \\
\text { power processing. }\end{array}$ & $\begin{array}{l}\text { - Hard switching at turn- } \\
\text { on for the main switch } \\
\text { and main diode at turn- } \\
\text { off, given rise to large } \\
\text { reverse recovery losses. } \\
\text { - Does not support } \\
\text { variable switching } \\
\text { frequency operation } \\
\text { - ZCT converter has high } \\
\text { voltage stress for the } \\
\text { diodes which are twice } \\
\text { as high as in the PWM } \\
\text { converters. }\end{array}$ \\
\hline Application & $\begin{array}{l}\text { - Suitable for } \\
\text { high-frequency } \\
\text { operation }\end{array}$ & $\begin{array}{l}\text { - Effective for IGBTs in } \\
\text { reducing switching losses } \\
\text { than ZVS at low frequency }\end{array}$ & $\begin{array}{l}\text { Applicable in high } \\
\text { voltage high-frequency } \\
\text { switched-mode power } \\
\text { conversion application. } \\
\text { - Deemed most suitable } \\
\text { for MOSFET based } \\
\text { power converters }\end{array}$ & $\begin{array}{l}\text { Reduced switching losses } \\
\text { for the main switch with } \\
\text { auxiliary switch achieving } \\
\text { ZCS, while keeping the } \\
\text { corresponding device } \\
\text { voltage and current } \\
\text { minimum, which are very } \\
\text { suitable for IGBT } \\
\text { applications. }\end{array}$ \\
\hline
\end{tabular}

\section{CONCLUSION}

Soft-switching techniques made possible the increasing demand of higher frequency converters with higher power density, high efficiency, compact size, and low EMI and losses. This article focus on various soft-switching techniques.

Emphasis had been given to general family classification soft-switching techniques which have been further classified. Quasi-resonant converters (QRC) active switch are subjected to low current stress, thus, the operation of these converters relay heavily on frequency control. Similarly, peak voltage resulting from resonant tank necessitates more highly rated device. MRC have moderate voltage stress on the switches and their conduction losses when compared to QRC is on the higher side. MRC is suitable for high-frequency operation. RTC has a .Icomplex control system, due to additional switch which also increases conduction losses, however, voltage and current stress of these converters are low. Furthermore, ZVS/ZCS reduces switching losses at turn-on and turn-off at the expense of high voltage/current stress. ZVT \& ZCT provides soft-switching with minimum voltage/current stress on the main switch, perhaps these converters are faced with problems of limited voltage conversion range and variable frequency operation.

\section{REFERENCES}

[1] Genc N, Koc Y. Experimental verification of an improved soft-switching cascade boost converter. Electr Power Syst Res [Internet]. 2017 Aug 1 [cited 2017 Sep 29];149:1-9. Available from: http://www.sciencedirect.com/science/article/pii/S0378779617301621

[2] Guo R, Liang Z, Huang AQ. A family of multimode charge pump based DC-DC converter with high efficiency over wide input and output range. IEEE Trans Power Electron. 2012;27(11):4788-98.

[3] Huang W, Moschopoulos G. A New Family of Zero-Voltage-Transition PWM Converters With Dual Active Auxiliary Circuits. IEEE Trans Power Electron. 2006;21(2):370-9. 
[4] Jiang L, Mi CC, Li S, Yin C, Li J. An improved soft-switching buck converter with coupled inductor. IEEE Trans Power Electron. 2013;28(11):4885-91.

[5] Do H-L. Soft-Switching SEPIC Converter With Ripple-Free Input Current. Ieee Trans Power Electron. 2012;27(6):2879-87.

[6] Agrawal B, Preindl M, Emadi A. Turn-off Energy Minimization for Soft-Switching Power Converters with Wide Bandgap Devices. In: 7th Power Electronics, Drive Systems and Technologies Conference, PEDSTC 2016. 2017.

[7] Smith KM, Smedley KM. Properties and synthesis of passive lossless soft-switching PWM converters. IEEE Trans Power Electron. 1999;14(5):890-9.

[8] Tahami F, Yazdani F. Zero-voltage-Transition with dual resonant tank for bridgeless boost PFC rectifier with low current stress. 7th Power Electron Drive Syst Technol Conf PEDSTC 2016. 2016;(Pedstc):241-7.

[9] Mohammadi M, Farzanehfard H, Adib E, Rezvanyvardom M. Analysis, design and implementation of zero-current transition interleaved boost converter. IET Power Electron [Internet]. 2012;5(9):1804-12. Available from: http://digital-library.theiet.org/content/journals/10.1049/iet-pel.2011.0419

[10] Lin BR, Huang CL. Analysis and implementation of zero voltage switching integrated buck-flyback converter. Int Rev Electr Eng. 2011;6(7):2846-52.

[11] Shenbagalakshmi R, Raja SR. Closed Loop Control of Soft Switched Interleaved Buck Converter. Int J Power Electron Drive Syst. 2012;2(3):313-24.

[12] Mohammadi MR, Farzanehfard H. A New Family of Zero-Voltage-Transition Nonisolated Bidirectional Converters with Simple Auxiliary Circuit. IEEE Trans Ind Electron. 2016;63(3):1519-27.

[13] Paprikar, Mohit and Akash G. Soft-Switching DC - DC Converter for Energy Applications. Int J Electron Electr Comput Syst. 2016;5(5):26-30.

[14] Zhang Y, Sen PC. A new soft-switching technique for buck, boost, and buck-boost converters. IEEE Trans Ind Appl. 2003;39(6):1775-82.

[15] Wang CM. Novel zero-voltage-transition PWM DC - DC converters. IEEE Trans Ind Electron. 1994;9(2):213-9.

[16] Hua G, Jiang Y, Lee FC, Yang EX. Novel zero-current-transition PWM converters. IEEE Trans Power Electron. 1994;9(6):601-6.

[17] Bodur H, Bakan AF. A new ZVT-PWM dc-dc converter. IEEE Trans Power Electron. 2002;17(1):40-7.

[18] Bodur H, Bakan a F. A New ZVT - ZCT - PWM DC - DC Converter. IEEE Trans Power Electron. 2004;19(3):676-84.

[19] Wu T-F, Liang S-A. A systematic approach to developing single-stage soft switching PWM converters. Power Electron IEEE Trans [Internet]. 2001;16(5):581-593. Available from: http://ieeexplore.ieee.org/xpls/abs_all.jsp?arnumber=949491

[20] Shamsi P, Fahimi B. Design and development of very high frequency resonant DC-DC boost converters. IEEE Trans Power Electron. 2012;27(8):3725-33.

[21] Bellar MD, Wu TS, Tchamdjou A, Mahdavi J, Ehsani M. A review of soft-switched DC-AC converters. IEEE Trans Ind Appl. 1998;34(4):847-60.

[22] Tran D, Vu H, Yu S, Choi W. A Novel Soft-switching Full Bridge Converter with a Combination of a Secondary Switch and a Non-dissipative Snubber. In 2017

[23] Nakaoka TMYTM. Analysis, Design , and Performance Evaluations of an Edge-Resonant Switched Capacitor Cell-Assisted. IEEE Trans Power Electron. 2013;28(7):3363-78.

[24] Arias M, Lamar DG, Linera FF, Balocco D, Aguissa Diallo A, Sebastián J. Design of a soft-switching asymmetrical half-bridge converter as second stage of an LED driver for street lighting application. IEEE Trans Power Electron. 2012;27(3):1608-21.

[25] Xing Z, Ruan X, You H, Yang X, Yao D, Yuan C. Soft-switching operation of isolated modular DC/DC converters for application in HVDC grids. IEEE Trans Power Electron. 2016;31(4):2753-66.

[26] Tran DD, Vu HN, Yu S, Choi W. A Novel Soft-Switching Full-Bridge Converter with a Combination of a Secondary Switch and a Nondissipative Snubber. IEEE Trans Power Electron. 2018;33(2):1440-52.

[27] Pal A, Basu K. A Unidirectional Snubber Less Fully Soft-switched Single Stage Three Phase High Frequency Link DC / AC Converter. In: Future energy Electronics Conference and ECCE Asia. 2017. p. 1777-84.

[28] Wu H, Sun K, Li Y, Xing Y. Fixed-Frequency PWM-Controlled Bidirectional Current-Fed Soft-Switching SeriesResonant Converter for Energy Storage Applications. IEEE Trans Ind Electron [Internet]. 2017;64(8):6190-201. Available from: http://ieeexplore.ieee.org/document/7878628/

[29] Wu H, Ding S, Sun K, Zhang L, Li Y, Xing Y. Bidirectional Soft-Switching Series-Resonant Converter with Simple PWM Control and Load-Independent Voltage-Gain Characteristics for Energy Storage System in DC Microgrids. IEEE J Emerg Sel Top Power Electron [Internet]. 2017;5(3):995-1007. Available from: http://ieeexplore.ieee.org/document/7812591/

[30] Das M, Agarwal V. Design and Analysis of a High-Efficiency DC-DC Converter with Soft Switching Capability for Renewable Energy Applications Requiring High Voltage Gain. IEEE Trans Ind Electron. 2016;63(5):2936-44.

[31] Karimi E, Heidari M, Adib E. Soft-Switching Flyback Inverter with Lossless Passive Snubber for AC Module Applications. In: 8th Power Electronics, Drive System \& Technologies Conference (PEDSTC 2017). 2017. p. 14-6.

[32] Meier MB, Avelino S, Badin AA, Félix E, Romaneli R, Gules R. Soft-Switching High Static Gain DC-DC Converter Without Auxiliary Switches. IEEE Trans Ind Electron. 2017;0046(c).

[33] Smith KM, Smedley KM. A comparison of voltage-mode soft-switching methods for PWM converters. IEEE Trans Power Electron. 1997;12(2):376-86.

[34] Shen CL, Wu YE, Chen MH. A modified SEPIC converter with soft-switching feature for power factor correction. Proc IEEE Int Conf Ind Technol. 2008; 
[35] Elasser A, Torrey DA. Soft switching active snubbers for DC/DC converters. IEEE Trans Power Electron. 1996;11(5):710-22.

[36] Ye Y, Cheng KWE, Chen S. A High Step-up PWM DC-DC Converter With. IEEE Trans Power Electron. 2017;32(10):7739-49.

[37] Abu-Qahouq J, Batarseh I. Generalized analysis of soft-switching dc-dc converters. PESC Rec - IEEE Annu Power Electron Spec Conf. 2000;1(2):185-92.

[38] Outeiro M. T, Buja G CD. Resonant Power Converters. Power [Internet]. 2016;7(June):21-45. Available from: http://books.google.com/books?hl=en\&lr=\&id=MqZPnv47IagC\&pgis=1

[39] C.L. WAT\& F. Zero-Voltage-Switching Multiresonant Technique-a Novel Approach to Improve Performance of. IEEE Trans Power Electron. 1989;4(4):450-8.

[40] Ching TW, Chan KU. Review of Soft-Switching Techniques for High- Frequency Switched-Mode Power Converters. In: IEEE Vehicle Power and Propulsion (VPPC). 2008.

[41] Hanson AJ, Yang RS, Lim S, Perreault DJ. A Soft-Switched High Frequency Converter for Wide Voltage and Power Ranges. In: Telecommunications Energy Conference (INTELEC). 2016.

[42] Yang SP, Chen SJ, Huang CM, Chiou BK. A Novel Series Input Parallel Output Soft-Switching High Step-Down Converter: Analysis and Implementation. In: Industrial Technology (ICIT), IEEE International Conference. 2017. p. $36-41$.

[43] Tarzamni H, Babaei E, Gharehkoushan AZ. A Full Soft-Switching ZVZCS Flyback Converter Using an Active Auxiliary Cell. IEEE Trans Ind Electron. 2017;64(2):1123-9.

[44] Wang CM. A new family of zero-current-switching (ZCS) PWM converters. IEEE Trans Ind Electron. 2005;52(4):1117-25.

[45] Gu Y, Hang L, Chen S, Du Y. Research on Control Type Soft Switching Converters. In: 35th Annual IEEE Power Electronics Specialists Conference. 2004. p. 1470-5.

[46] Wang Y, Yang L, Li G, Tu S. A Parameter Selection Method for Multi-Element Resonant Converters with a Resonant Zero Point. J Power Electron. 2018;18(2):332-42.

[47] Martins ML, Russi JL, Hey HL. Low reactive energy ZCZVT PWM converters: Synthesis, analysis and comparison. PESC Rec - IEEE Annu Power Electron Spec Conf. 2005;2005:1234-40.

[48] Tuomainen V, Kyyrä J. Effect of resonant transition on efficiency of forward converter with active clamp and selfdriven SRs. IEEE Trans Power Electron. 2005;20(2):315-23.

[49] Martins ML, Russi JL, Pinheiro JR, Hey HL. Novel resonant transition PWM inverters: Synthesis and analysis. PESC Rec - IEEE Annu Power Electron Spec Conf. 2006;

[50] Akin B, Bodur H. A new single-phase soft-switching power factor correction converter. IEEE Trans Power Electron. 2011;26(2):436-43.

[51] Das P, Moschopoulos G. A zero-current-transition converter with reduced auxiliary circuit losses. INTELEC, Int Telecommun Energy Conf. 2005;22(4):545-50.

[52] F. EAH. Family of Isolated Zero Current Transition PWM Converters. J Power Electron. 2009;9(2):156-63.

[53] Wei H, Ioinovici A. Zero-voltage transition converter with high efficiency operating at constant switching frequency. IEEE Trans Circuits Syst I Fundam Theory Appl. 1998;45(11):1121-8.

[54] Lim J, Soh J, Kim R. An Improved Single-Phase Zero-Voltage Transition Soft-Switching Inverter with a Subtractive Coupled Inductor Auxiliary Circuit. In: IEEE. 2016. p. 1-6.

[55] Abdelhamid TH, Sabzali AJ. New three-phase ac-ac converter incorporating three-phase boost integrated ZVT bridge and single-phase HF link. Energy Convers Manag. 2008;49(5):1039-46.

[56] Yang J, Do H. Soft-Switching Dual-Flyback DC - DC Converter. IEEE Trans Ind Electron. 2017;64(5):3587-94.

[57] Wu H, Mu T, Ge H, Xing Y. Full-Range Soft-Switching-Isolated Buck-Boost. IEEE Trans Power Electron. 2016;31(2):987-99.

[58] a A. Boost Converters. Power. 2007;22(1):80-6.

[59] Durgam K.S RSB. A New Approach for Efficient Soft-Switching Technique to Increase Power Conversion. Int J Adv Technol Innov Res. 2016;08(24):4608-15.

[60] Rashid M, Czarkowski D. DC-DC Converters. Power Electron Handbook Devices, Circuits, Appl [Internet]. 2006;2(c):245-59. Available from: www.books.elsevier.com

[61] Mojtaba F, Siwakoti YP, Gorji SA, Blaabjerg F, Lehman B. Step-Up DC - DC Converters : A Comprehensive Review of Voltage-Boosting Techniques ,. IEEE Trans Power Electron. 2017;32(12):9143-78.

[62] Salem Mohamed JA, Nik Rumzi Nik Idris, Tole Sutikno YMB. Phase-shifted Series Resonant Converter with Zero Voltage Switching Turn-on and Variable Frequency Control. Int J Power Electron Drive Syst. 2017;8(3):1184-92.

[63] El Maguiri O, Giri F, El Fadil H, Chaoui FZ. Interconnected state observers for series resonant converters [Internet]. Vol. 42, IFAC Proceedings Volumes (IFAC-PapersOnline). IFAC; 2009. 296-301 p. Available from: http://dx.doi.org/10.3182/20090705-4-SF-2005.00053

[64] Bhuvaneswari C, Babu RSR. Analysis of High Voltage High Power Resonant Converters. Int J Power Electron Drive Syst. 2018;9(1):174-9.

[65] Elmaguiri O, Giri F, El Fadil H. Robust control of series resonant DC-to-DC power converters [Internet]. Vol. 42, IFAC Proceedings Volumes (IFAC-PapersOnline). IFAC; 2009. 284-289 p. Available from: http://dx.doi.org/10.3182/20090705-4-SF-2005.00051

[66] Chen J, Chen J, Bonert R. Load Independent AC/DC Power Supply for Higher Frequencies with Sine-Wave Output. IEEE Trans Ind Appl. 1983;IA-19(2):223-7. 
[67] Johnson SD, Witulski AF, Erickson RW. Comparison of resonant topologies in high-voltage DC applications. IEEE Trans Aerosp Electron Syst [Internet]. 1988;24(3):263-74. Available from: http://ieeexplore.iee.org/document/192094/

[68] Bhat AKS, Dewan SB. A generalized approach for the steady-state analysis of resonant inverters. IEEE Trans Ind Appl. 1989;25(2):326-38.

[69] Steigerwald RL. A comparison of high-power DC-DC soft-switched converter topologies. IEEE Trans Ind Appl. 1996;32(5):1139-45.

[70] Riedel J, Holmes DG, McGrath BP, Teixeira C. ZVS soft switching boundaries for dual active bridge DC-DC converters using frequency domain analysis. IEEE Trans Power Electron. 2017;32(4):3166-79.

[71] Lin, BR HF. Soft-Switching Zeta - Flyback Converter With a Buck - Boost Type of Active Clamp. Ind Electron IEEE Trans [Internet]. 2007;54(5):2813-22. Available from: http://ieeexplore.ieee.org/xpls/abs_all.jsp?arnumber=4294276

[72] Zacharias AM, Devaprakash TR. Modeling and simulation of photovoltaic system with soft switching SEPIC converter. 2014 Annu Int Conf Emerg Res Areas Magn Mach Drives, AICERA/iCMMD 2014 - Proc. 2014;(1).

[73] Seong HW, Kim HS, Park KB, Moon GW, Youn MJ. High step-up DC-DC converters using zero-voltage switching boost integration technique and light-load frequency modulation control. IEEE Trans Power Electron. 2012;27(3):1383-400

[74] Corradini L, Seltzer D, Bloomquist D, Zane R, Maksimović D, Jacobson B. Zero voltage switching technique for bidirectional dc/dc converters. IEEE Trans Power Electron. 2014;29(4):1585-94.

[75] Du C, Xu D, He N, Zhu N. Modeling and Optimization of a Zero Voltage Switching Inverter for High Efficiency and Miniaturization. IEEE Trans Power Electron. 2017;32(1):150-63.

[76] Mehdi Radmehr, Venus Tahmasebi IY. Design and Implementation of a New DC/DC Converter with ZVS and High Gain. In: IEEE Asia-Pacific Power and Energy Conference. 2016. p. 472-7.

[77] Ekhtiari M, Zhang Z, Andersen MAE. Analysis of Bidirectional Piezoelectric-Based Converters for Zero-Voltage Switching Operation. IEEE Trans Power Electron. 2017;32(1):866-77.

[78] De A, Barai M. An improved zero voltage switching SVPWM for three phase inverter. 11th IEEE Int Conf Compat Power Electron Power Eng CPE-POWERENG 2017. 2017;169-74.

[79] Manoel C, Duarte C, Barbi I. An Improved Family of ZVS-PWM Active-Clamping DC-to-DC Converters. IEEE Trans Power Electron. 2002;17(1):1-7.

[80] Ma G, Qu W, Yu G, Liu Y, Liang N, Li W. A zero-voltage-switching bidirectional DC-DC converter with state analysis and soft-switching-oriented design consideration. IEEE Trans Ind Electron. 2009;56(6):2174-84 .

[81] Tao CW, Wang CM, Chang CW. A design of a DC-AC inverter using a modified ZVS-PWM auxiliary commutation pole and a DSP-based PID-like fuzzy control. IEEE Trans Ind Electron. 2016;63(1):397-405.

[82] Maali E, Vahidi B. Double-Deck Buck-Boost Converter with Soft Switching Operation. IEEE Trans Power Electron. 2016;31(6):4324-30.

[83] Mallik A, Khaligh A. A soft-switching strategy for three-phase boost power factor correction rectifiers. IECON Proc (Industrial Electron Conf. 2016;5603-8.

[84] Alam M, Eberle W, Gautam DS, Botting C. A Soft-Switching Bridgeless AC - DC Power Factor Correction Converter. IEEE Trans Power Electron. 2017;32(10):7716-26.

[85] Ting, Nairn Suleyman NA. A Soft Switching Single Phase Power Factor Correction AC-DC Boost Converter with Passive Snubber. In: 2017th international conference on electrical electronics engineering. 2017. p. 13-7.

[86] Kumar AP, Bhajana VVSK, Drabek P. A novel ZVT/ZCT bidirectional DC-DC converter for energy storage applications. In: 2016 International Symposium on Power Electronics, Electrical Drives, Automation and Motion (SPEEDAM) [Internet]. 2016. p. 979-83. Available from: http://files/1218/7525964.html

[87] Moorthy RSK, Rathore AK. Zero current switching current-fed parallel resonant push-pull (CFPRPP) converter. 2014 Int Power Electron Conf IPEC-Hiroshima - ECCE Asia 2014. 2014;3616-23.

[88] Lee Y, Lin Y, Hsiao S, Ko Y. Multiple Output Zero-Current Switching Bi-directional Converter. In: 33rd annual conference of the IEEE Industrial Electronics Society (IECON). 2007. p. 2058-63.

[89] Cancelliere P, Colli VD, Di Stefano R, Marignetti F. Modeling and control of a zero-current-switching DC/AC current-source inverter. IEEE Trans Ind Electron. 2007;54(4):2106-19.

[90] Mousavi A, Das P, Moschopoulos G. A comparative study of a new ZCS DC-DC full-bridge boost converter with a ZVS active-clamp converter. IEEE Trans Power Electron. 2012;27(3):1347-58.

[91] Amini MR, Farzanehfard H, Emrani A, Mahdavi M. Soft switching bridgeless power factor correction with reduced conduction losses and no stresses. IET Power Electron [Internet]. 2012;5(3):334-40. Available from: http://digitallibrary.theiet.org/content/journals/10.1049/iet-pel.2011.0101

[92] Canesin CA, Barbi I. Novel Zero-Current-Switching PWM Converters. IEEE Trans Ind Electron. 1997;44(3):37281.

[93] Qin L, Xie S, Zhou H. A novel family of PWM converters based on improved ZCS switch cell. PESC Rec - IEEE Annu Power Electron Spec Conf. 2007;(3):2725-30.

[94] Fuentes RC. An Improved ZCS-PWM Commutation Cell for IGBT' s Application. IEEE Trans Power Electron. 1999;14(5):939-48.

[95] Carlos M, Oliveira Stein De HLH. A True ZCZVT Commutation Cell for PWM Converters. IEEE Trans Power Electron. 2000;15(1):185-93.

[96] Barbari I. Bolacell J.C, Martins D.C LF. Buck Quasi-Resonant Converter Operating at Constant Frequency: Analysis, Design, and Experimentation. IEEE Trans Power Electron. 1990;5(3):276-83. 
[97] Ivensky G, Sidi D, Ben-yaakov S, Box P. A Soft Switcher Optimized for IGBTs in PWM Topologies. In: IEEE APEC. 1995. p. 900-6.

[98] Al-Saffar MA, Ismail EH, Sabzali AJ. Family of ZC-ZVS converters with wide voltage range for renewable energy systems. Renew Energy [Internet]. 2013;56:32-43. Available from: http://dx.doi.org/10.1016/j.renene.2012.12.037

[99] Wu X, Xie X, Zhao C, Qian Z, Zhao R. Low voltage and current stress ZVZCS full bridge DC-DC converter using center tapped rectifier reset. IEEE Trans Ind Electron. 2008;55(3):1470-7.

[100] K.S. HRM. A Soft-Switching Scheme for an Isolated DC / DC Converter With Pulsating DC Output for a. IEEE Trans Power Electron. 2009;24(10):2276-88.

[101] Kim M, Choi S. A fully soft-switched single switch isolated DC-DC converter. IEEE Trans Power Electron. 2015;30(9):4883-90.

[102] Ruan X, Yan Y. A Novel Zero-Voltage and Zero-Current-Switching PWM Full-Bridge Converter Using Two Diodes in Series With the Lagging Leg. IEEE Trans Ind Electron [Internet]. 2001 [cited 2017 Jun 19];48(4):77785. Available from: http://ieeexplore.ieee.org/abstract/document/937410/

[103] H AR, Zainal S. A Family of True Zero Voltage Zero Current Switching ( ZVZCS ) Nonisolated Bidirectional DC - DC Converter With Wide Soft Switching Range. IEEE Transation Ind Electron. 2017;64(7):5416-27.

[104] Halder T, Ieee M, Nadia D-, Bengal W. An Improved Performance of the Soft Switching Buck Converter. In: 2016 International conference on control, instrumentation, energy and communication (CIEC). 2016. p. 309-13.

[105] Wang C, Lin C, Kuo H, Lin C. Zero-Current Transition Interleaved Boost DC / DC Converter. TENCON 2013 2013 IEEE Reg 10 Conf (31194), Xi'an, 2013. 2014;278-81.

[106] Mao H, Lee FCY, Zhou X. Improved Zero-Current Transition Converters for High-Power Applications. IEEE Trans Ind Appl. 1997;33(5):1220-32.

[107] M.T; GKMMRSARM. The State Space Average Model of Boost Switching Regulator Including All of the System Uncertainties. Adv Mater Res. 2012;403-408:3476-83.

[108] Farzanehfard H, Beyragh DS, Adib E. A bidirectional soft switched ultracapacitor interface circuit for hybrid electric vehicles. Energy Convers Manag [Internet]. 2008;49(12):3578-84. Available from: http://dx.doi.org/10.1016/j.enconman.2008.07.004

[109] Bazinet J, O'Connor JA. Analysis and design of a zero voltage transition power factor correction circuit. Appl Power Electron Conf Expo 1994 APEC '94 Conf Proc 1994, Ninth Annu. 1994;591-7 vol.2.

[110] Barbi I, Ieee SM. A family of DC-to-DC PWM Converter Using a New ZVS commutation Cell. In: IEEE Power Electronics Special Conference. 1993. p. 524-30.

\section{BIOGRAPHIES OF AUTHORS}
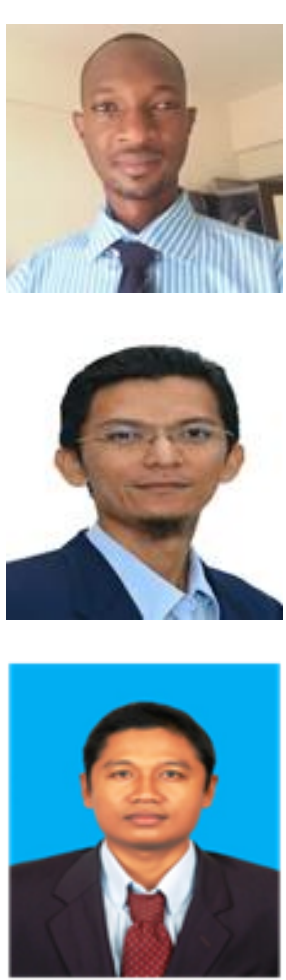

AbdulHakeem Mohammed Dobi obtained B.Eng and M.Eng in Electrical Engineering from Bayero University, Kano Nigeria, in 2005 and 2012 respectively. Currently, he is pursuing a Ph.D. in power electronics at the Universiti Teknologi Malaysia (UTM) Johor Bahru. His research interest includes Soft switching, Resonance DC-DC converters, and their control aspects.

Dr. Mohd Rodhi Bin Sahid is a senior lecturer in the Department of Electrical Power system, Universiti Teknologi Malaysia, Johor Bahru Malaysia. He obtained B.Eng.; M.Eng and Ph.D. in Electrical Engineering. He has published many papers in the field of power electronics. His area of interest includes power factor correction, DC-DC converters

Tole Sutikno is an Associate Professor in Electrical \& Computer Engineering Department Universitas Ahmad Dahlan, Yogyakarta, Indonesia. He receives B.Eng.; M.Eng; and Ph.D. degrees in 1999, 2004 and 2016 respectively. He has over 198 publication to his credit. His research interest in is the power electronics, motor drives, industrial electronics, Industrial application, FPGA application, intelligence control and Industrial informatics 